\title{
Towards a European Health Union: Time to Level Up
}

\author{
Alberto ALEMANNO*
}

The European response to COVID-19 has revealed an inconvenient truth. Despite having integrated public health concerns across all its policies - be it agriculture, consumer protection or security ${ }^{1}-$, the Union cannot act directly to save people's lives, even in an emergency. ${ }^{2}$ Only Member States are entitled to do so. Yet when they have adopted unilateral measures to counter the spread of the virus, those have proved not only ineffective but also disruptive to vital supply chains and the mobility of millions of citizens by ultimately preventing the flow of essential goods and people across the Union. These fragmented efforts in tackling cross-border health threats make all Member States collectively more vulnerable. The only way for the EU to protect public health - through the adoption of binding legislation - is by relying on nonhealth-related competences, which are dispersed across the Treaties. This is what the Union has been doing over decades, by regulating the placing into the market of medicines, food, feed, biotech products, blood, human organs, tobacco and alcohol as well as by recognising medical qualifications and patients' rights to be treated across the Union. So much for a EU public health policy: a panoply of scattered regulatory frameworks that have emerged over time in order to enable the Union to operate as an internal market for goods, services and workers.

Despite some previous attempts at unveiling such an imperfect reality to the many (think of BSE in the 1990s or SARS and bird flu in the 2000s), the structural, ontological status of health in the EU has remained one of the best kept secrets among EU insiders for a long time. This state of affairs was symbolised by the total lack of citizen awareness of - and attention given to - the existence of a dedicated

\footnotetext{
* Jean Monnet Professor of European Union Law, HEC Paris; email: alemanno@ hec.fr. Editor of Special Issue "Beyond COVID-19: Towards a European Health Union" (2020) 4 European Journal of Risk Regulation.

1 See Art 9 TFEU. While mainstreaming obligations do not expand EU competence, they help achieve coherence between policies and actions within existing spheres of competence with a view of taking all EU objectives into account.

2 The Health Security Committee convened more than 40 times from January to November 2020, to coordinate an EU health response. Yet it has no ability to enforce commonly agreed approaches or coordinate national responses around control measure. See eg L Cabane and AL Beaussier, "Strengthening the EU's Response Capacity to Health Emergencies: Insights from EU Crisis Management Mechanisms", in this Special Issue (EJRR 2020). See also Communication from the Commission to the European Parliament, the Council, the European Economic and Social Committee and the Committee of the Regions, "Building a European Health Union: Reinforcing the EU's resilience for cross-border health threats", Brussels (11 November 2020), COM(2020) 724 final, pp 5-7.
} 
EU agency, the European Centre for Disease Prevention and Control (ECDC), tasked to strengthen "Europe's defences against infectious diseases".

The current pandemic has suddenly exposed this deficient framework to the many. It is no surprise that over two-thirds of EU citizens now expect the EU to have a more active role in protecting their health, particularly in protecting them from health threats that transcend national borders. ${ }^{3}$ This represents a major political and historical opportunity for EU leaders to rethink the role that public health should play in the realisation and operation of the Union. It also raises the taboo question of what is the minimum level of health care that each Member State should provide in order for the Union to defend itself from cross-border pathogens.

In short, the interlocking damage caused by the pandemic in the health, economic and social sectors contributed to highlight the obvious: health is a precondition for our society and economy to function. As such, the EU's limited and imperfect competences in public health have very quickly prompted political calls for the urgent creation of a European Health Union. ${ }^{4}$ This call, which initially emerged out of the first phase of the pandemic, has in the meantime been endorsed by EU Commission President Ursula von der Leyen who, in her State of the Union address on 16 September 2020, stated:

For me, it is crystal clear - we need to build a stronger European Health Union.

And to start making this a reality, we must now draw the first lessons from the health crisis.

We need to make our new EU4Health programme future proof. And we need to strengthen our crisis preparedness and management of cross-border health threats.

As a first step, we will propose to reinforce and empower the European Medicines Agency and ECDC - our centre for disease prevention and control.

As a second step, we will build a European BARDA - an agency for biomedical advanced research and development. This new agency will support our capacity and readiness to respond to cross-border threats and emergencies - whether of natural or deliberate origin. We need strategic stockpiling to address supply chain dependencies, notably for pharmaceutical products.

As a third step, it is clearer than ever that we must discuss the question of health competences. And I think this is a noble and urgent task for the Conference on the Future of Europe.

\footnotetext{
3 "Public Opinion in Times Of Covid-19. A Public Opinion Survey Commissioned by the European Parliament First Results - 14 July 2020" (European Parliament 2020) <www.europarl.europa.eu/at-your-service/files/be-heard/ eurobarometer/2020/public_opinion_in_the_eu_in_time_of_coronavirus_crisis_2/en-covid19-survey2-key-findings. pdf $>$ (last accessed 27 November 2020).

4 European Parliament resolution of 10 July 2020 on the EU's public health strategy post-COVID-19 (2020/2691/ RSP), calling "for the European institutions and the Member States to draw the right lessons from the COVID-19 crisis and engage in far stronger cooperation in the area of health; calls therefore for a number of measures to create a European Health Union".
} 
Far from offering a template, this presidential call merely prodded EU Member States to take public health more seriously, by not excluding the possibility of devolving more competences to the Union. ${ }^{5}$

As such, von der Leyen's call for the establishment of a Health Union raises more questions than answers. And some are quite uncomfortable questions.

How many lives would a European Health Union have saved? How best to prepare for future health emergencies? Does strengthened coordination at EU level necessarily entail the creation of a Health Union? What does it take to build a European Health Union? And what would it look like? Will the Health Union be pandemic-proof ahead of the next virus?

As a growing number of policymakers, observers and commentators are confronted with these hard questions, this Special Issue of the European Journal of Risk Regulation gathers a distinguished group of scholars who have been studying and thinking for a long time about the role public health should play within the Union. With the aim of offering a rigorous and timely blueprint to decision-makers and the public at large, we asked them to contextualise such a new political project within the broader constitutional and institutional framework of EU public health law and policy.

In the meanwhile, the EU has published a Communication aimed at sketching up the main building blocks for a European Health Union. ${ }^{6}$ In doing so, the Union finds itself in the paradoxical situation of invoking the need to "contribute to a more resilient EU internal market and a sustained economic recovery" in order to justify its action. In other words, in line with the logic that has sustained the development of EU health law and policy over the years, the trigger prompting the Union to build a Health Union is not public health, but the economy.

However, when it comes to the chosen legal basis, the Communication shows readiness to pioneer the use of Article 168(5) TFEU. This untested provision, introduced by the Lisbon Treaty, ${ }^{7}$ states that:

The European Parliament and the Council, acting in accordance with the ordinary legislative procedure and after consulting the Economic and Social Committee and the Committee of the Regions, may also adopt incentive measures designed to protect and improve human health and in particular to combat the major crossborder health scourges, measures concerning monitoring, early warning of and

\footnotetext{
5 This does not automatically entail entrusting a supranational EU authority with making decisions on health crises, but could - more realistically and appropriately - confer on the Union greater supervision of the coordination of Member States' responses to cross-border health threats, so as to make such coordination binding.

6 Communication from the Commission to the European Parliament, the Council, the European Economic and Social Committee and the Committee of the Regions, "Building a European Health Union: Reinforcing the EU's resilience for cross-border health threats", $\operatorname{COM}(2020) 724$ final (11 November 2020).

7 On these provisions, see eg KP Purnhagen et al, "More Competences than You Knew? The Web of Health Competence for European Union Action in Response to the COVID-19 Outbreak" (2020) 11 European Journal of Risk Regulation 297; A Alemanno, "The European Response to COVID-19: From Regulatory Emulation to Regulatory Coordination?" (2020) 11 European Journal of Risk Regulation 307. For a deeper, more systematic examination, A de Ruijter, EU Health Law \& Policy: The Expansion of EU Power in Public Health and Health Care (Oxford Studies in European Law; Oxford: Oxford University Press 2019).
} 
combating serious cross-border threats to health, and measures which have as their direct objective the protection of public health regarding tobacco and the abuse of alcohol, excluding any harmonisation of the laws and regulations of the Member States.

The Commission put forward four legislative proposals, two of them on this legal basis. The first is an upgrading of the EU primary tool for managing health crises - the $2013 \mathrm{EU}$ Regulation on serious cross-border threats to health - as it proved manifestly inadequate in the first phase of the pandemic. ${ }^{8}$ The second proposal, also based on Article 168(5), intends to align the mandate of the ECDC to this new framework. ${ }^{9}$ In turn, a third proposal extends the mandate of the European Medicines Agency (EMA) and also links it to a fourth Commission proposal for enhancing the Union Civil Protection Mechanism. ${ }^{10}$

So much for a European Health Union $!^{11}$ In essence, the current proposals amount to a tweak of pre-existing mechanisms and institutional frameworks and intend to overcome their major, by now manifest, limitations, which were brought to light by COVID-19. Yet the disturbing reality is that these EU solidarity mechanisms, from the EU Civil Protection Mechanism to the EU health security framework - ie the Health Security Committee (HSC) and Early Warning and Response System (EWRS) - already offered ways to offset many of these problems, but they were simply not used enough (civil protection) or were inadequate (health security framework). In other words, in the first phase of the pandemic and its unfolding the EU could largely have avoided the adoption of a wide variety of uncoordinated national control measures, such as social distancing, mask wearing or cross-border checks, not to mention export restrictions on personal protective equipement.

The open question is therefore whether this further upgrade of the EU health framework to counter cross-border health threats is qualitatively different from previous attempts to update it.

As our brief excursus of the Union's Health Union demonstrates, the envisaged European Health Union won't entail a Copernican revolution - not even in the

\footnotetext{
8 Decision No 1082/2013/EU of the European Parliament and of the Council of 22 October 2013 on serious crossborder threats to health and repealing Decision No 2119/98/EC Text with EEA relevance (5 November 2013), OJ L 293, pp 1-15.

9 Proposal for a Regulation of the European Parliament and of the Council amending Regulation (EC) No 851/2004 Establishing a European Centre for Disease Prevention and Control, Brussels (11 November 2020), Com(2020) 726 Final 2020/0320 (Cod).

10 Proposal For a Decision of the European Parliament and of the Council amending Decision No 1313/2013/EU on a Union Civil Protection Mechanism COM/2020/220 final. The Union Civil Protection Mechanism (UCPM) allows the Commission to support Member States in coordinating efforts to prevent and prepare for disasters as well as through its Emergency Response Coordination Centre (ERCC) in responding when their national capacities are overwhelmed by any kind of disaster, including ones such as COVID-19. Amidst the pandemic, EU Member States, UCPM Participating States and third countries resorted to the UCPM for support requesting in-kind assistance in the form of PPE and sanitation, but also requesting the support of medical teams.

11 There are several ongoing initiatives including recommendations of the Health Security Committee for a common testing approach for COVID-19 and the setting up of an EU Health Emergency Preparedness and Response Authority, as well as a pharmaceutical strategy aiming to create a future-proof regulatory framework for the entire lifecycle of a medicine.
} 
aftermath of the most severe public health crisis that the EU (and the world) has ever experienced.

Yet as the pandemic is still ongoing, one might expect EU legislators to tackle the root causes of what has prevented the Union from responding effectively to COVID19. These causes largely consist of - and reflect - the structural inequalities in health care capacity across the Union. As such, they range from the inadequacy of public resources invested in the health system - with major variations across Member States ${ }^{12}$ - to fragmented population coverage, ranging from the inadequate availability of services, especially in rural areas, to difficulties in reaching particularly vulnerable groups.

Health care is, and is set to remain, in the hands of the Member States, even despite further incremental attempts at nudging Member States to coordinate or supplement the exercise of their competence. This is not set to change. Yet what EU citizens expect from the Union ahead of the next pan-European health crisis has already changed. ${ }^{13}$

Unless the Union embeds into the Health Union a more harmonised health care system of consistent quality, the new health system won't be qualitatively different from what it is today.

This quantum leap may be operationalised by a directive on minimum standards for quality health care. This would entail the introduction of a set of common criteria to be reported to the European Commission on a regular basis, using parameters such as hospital beds per head, critical care capacity, numbers of doctors and nurses per head, rate of health expenditure and access and affordability of health care for all, including for vulnerable populations. While the management, organisation and funding of health care systems would remain Member State competences, EU minimum standards for quality health care would guarantee pan-EU resilience in the face of pandemics and other public health crises, by increasing overall health care capacity across Member States. This approach, by levelling up health care across the Union, would address upstream many weaknesses of today's fragmented EU health policy, including the absence of prescriptive EU supervision of the substance of preparedness plans and their enforcement. Moreover, by requiring convergence among national health sectors, it would build a genuine pan-EU health care infrastructure ahead of future health emergencies.

At a time when Member States' health systems have received greater attention, health inequalities have also appeared. Turning a blind eye to this reality seems shortsighted, all the more so when the declared objective of the European Health Union is to strengthen the EU's resilience to cross-border health threats.

12 There is a huge variety in the amount of public resources spent on health care across EU member states, ranging from 3\% of GDP in Cyprus to 9.4\% of GDP in Germany. This leads to large variations in the availability and quality of services. In some countries, public health care funding has been drastically reduced as a result of expenditure cuts following the 2008 economic and financial crisis (e.g. CY, EL, ES, IS, IT, PT). See R Baeten, S Spasova, B Vanhercke and S Coster, "Inequalities in access to health care: A study of national policies" (European Commission, Directorate-General for Employment, Social Affairs and Inclusion 2018).

13 See supra, note 3 (Eurobarometer 2020). 